\title{
POLYPHENOLIC CONTENT AND SENSORY PROFILE OF MONTENEGRIN VRANAC WINES PRODUCED WITH DIFFERENT OENOLOGICAL PRODUCTS AND MACERATION
}

\author{
Danijela Raičević ${ }^{1, *}$, Zvonimir Božinović ${ }^{2}$, Mihail Petkov ${ }^{2}$, Violeta Ivanova-Petropulos ${ }^{3}$, \\ Vesna Kodžulović ${ }^{4}$, Milena Mugoša ${ }^{4}$, Sanja Šućur ${ }^{4}$, Vesna Maraš ${ }^{4}$ \\ ${ }^{1}$ Biotechnical Faculty, University of Montenegro, Mihaila Lalića 1, Podgorica, Montenegro \\ ${ }^{2}$ Faculty of Agriculture, Ss. Cyril and Methodius University, \\ Aleksandar Makedonski bb, Skopje, Republic of Macedonia \\ ${ }^{3}$ Faculty of Agriculture, University Goce Delčev - Śtip, \\ Krste Misirkov bb, Stip, Republic of Macedonia \\ ${ }^{4}$ 13. jul Plantaže, Put Radomira Ivanovića 2, Podgorica, Montenegro
}

\begin{abstract}
Polyphenolic compounds, including total phenolics (TP), total anthocyanins (TA) and total flavan3-ols $\left(\mathrm{TF}_{3 \text {-ols }}\right)$, as well as color intensity $(\mathrm{CI})$ and hue $(\mathrm{H})$, determined by spectrophotometric methods, were studied in Montenegrin red wines from Vitis vinifera L. cv, Vranac. Wines were produced by traditional and modern fermentation methods, applying different oenological products (enzyme, oak chips and grape tannins) during two vintages, i.e. 2008 and 2009. Wines produced from the 2009 vintage presented a slightly higher average amount of total phenols $(2,878 \mathrm{mg} / \mathrm{l})$ compared to the wines from the 2008 vintage $(2,570 \mathrm{mg} / \mathrm{l})$, and similar contents of anthocyanins and flavan-3-ols. The use of modern fermentation tanks (Sifa and Ganimede) followed by the addition of enzymes, oak chips and grape tannins resulted in a higher amount of polyphenolic compounds. Principal components analysis allowed for the grouping of wines according to the vintage and maceration method.
\end{abstract}

Keywords: total phenols; anthocyanins; flavan-3-ols, color intensity, hue; wine fermentation; oenological additions

\section{СОДРЖИНА НА ПОЛИФЕНОЛИ И СЕНЗОРЕН ПРОФИЛ НА ВИНАТА ВРАНЕЦ ОД ЦРНА ГОРА ПРОИЗВЕДЕНИ СО РАЗЛИЧНИ ЕНОЛОШКИ ПРОИЗВОДИ И МАЦЕРАЦИЈА}

Полифенолните соединенија, вклучувајќи вкупни феноли (ВФ), вкупни антоцијани (ВА), вкупни флаван-3-оли (ВФ3-оли), како и интензитет на боја (ИБ) и нијанса $(\mathrm{H})$, определени со примена на спектрофотометриски методи, беа проучувани во црвени вина од Црна Гора од Vitis vinifera, сортата вранец. Вината беа произведени во текот на две години, 2008 и 2009, со традиционални и модерни методи на ферментација, со примена на различни енолошки средства (ензим, дабов чипс и танини од грозје). Вината произведени во 2009 година имаа малку повисока содржина на вкупни феноли (2 $878 \mathrm{mg} / \mathrm{l})$ во споредба со вината од 2008 година (2 $570 \mathrm{mg} / \mathrm{l})$ и имаа слична содржина на антоцијани и флаван-3-оли. Примената на модерни резервоари за ферментација (Сифа и Ганимеде), и со додавањето на ензими, дабов чипс и танини од грозје, резултираше со добивање вино побогато со полифеноли. Карактеристичната векторска анализа овозможи групирање на вината според годината на производство и применетиот метод за мацерација.

Клучни зборови: вкупни феноли; антоцијани; флаван-3-оли; интензитет на боја; нијанса; ферментација; енолошки средства 


\section{INTRODUCTION}

Wine is a complex alcoholic beverage, in which the matrix plays an important role in the perceived aroma, flavor and taste of the final product [1]. It contains variety of compounds such as polyphenols, organic acids, carbohydrates, aroma compounds (alcohols, esters), metals, etc. Phenolic compounds are considered to be the main factors responsible for the quality of grapes and consequently for the corresponding wines, influencing the color, mouthfeel, astringency and bitterness of the wine [2]. Phenolics belong to two groups: flavonoids (flavonols, flavan-3-ols and anthocyanins) and non-flavonoids (the phenolic acids hydroxybenzoic and hydroxycinnamic acids and their derivatives, as well as stilbenes). Red wines contain all the above phenolics, while white wines contain mainly phenolic acids and flavanols [3]. Anthocyanins are red pigments responsible for the red color of wines. The most important grape and wine anthocyanins are the 3-glucoside forms of cyanidin, peonidin, petunidin, delphinidin and malvidin [4]. Flavonols are mainly present as 3glycosides and 3-glucuronides of quercetin and myricetin, 3-glucosides of kaempferol and isorhamnetin, and laricitrin and syringetin, predominantly found as 3-glucosides [5]. The major flavan-3-ol monomers are (+)-catechin, (-)epicatechin and (-)-epicatechin-3-O-gallate [6]. Proanthocyanidins, also called condensed tannins, are compounds responsible for bitterness and astringency of red wines $[7,8]$. Since the properties of proanthocyanidins depend on their structures, low molecular weight flavan-3-ols, such as catechins and procyanidin oligomers are responsible for the bitterness; and polymeric flavan-3-ols are largely responsible for red wine astringency [9].

Technological practices that are applied for winemaking, such as maceration, the addition of $\mathrm{SO}_{2}$, yeast, enzymes and oak chips, the control of fermentation temperature and the conditions of storage and wine aging affect the content of polyphenols; thus, they have an impact on wine quality [10-16]. Maceration is a very important phase in the production of high quality red wines as it leads to increased color stability and improved taste and flavor as well as overall better wine quality. During the first days of maceration, the content of anthocyanins increases due to their extraction from the grape skins. Conversely, tannin extraction from seeds starts at the mid-point of alcoholic fermentation and continues until pressing during the postfermentation phase [16].
During winemaking, different oenological products can be used. Enzymes are commonly used to improve the most important characteristics of wine, such as color and aroma; tannin extraction is also increased, resulting in improved complexity, mouthfeel and stability of the wine $[17,18]$. Pectinases are the main enzymes used in winemaking, which can occur naturally in grapes or can obtained as a commercial preparation. Usage of oak chips or grape tannins positively affects the sensorial and chemical quality of wine, improving the intensity and complexity of flavor and aroma of wines, reducing the astringency and bitterness, and stabilizing the color $[19,20]$. Furthermore, the use of oak chips and/or grape tannins allows for fermentation in stainless steel tanks, obtaining wines with decreased astringency and bitterness, similar to those fermented in barrels [21].

Vranac is a Montenegrin autochthonous grape variety, used for the production of high quality red wines [22-25]. Outside of Montenegro, it is planted in the Republic of Macedonia, Serbia and Croatia (Dalmatia). The main purpose of this study was to study and compare the effects of different parameters, such as the addition of enzymes, oak chips and grape tannins on the extraction of grape phenolic compounds during traditional and modern maceration, applying spectrophotometric methods for the determination of total phenolics, total anthocyanins and total flavan-3-ols, as well as the color intensity and hue of Vranac wines. In addition, a sensorial analysis of all produced wines was performed in order to reveal their sensorial characteristics.

\section{EXPERIMENTAL}

\subsection{Chemicals and reagents}

The reagent $p$-(dimethylamino)cinnamaldehyde ( $p$-DMACA), the standard of (+)-catechin were purchased from Fluka (Switzerland) and the Folin-Ciocalteu reagent was obtained from Merck (Germany). The standard of malvidin-3-glucoside was purchased from Extrasynthese (Genay, France). All the other reagents used were of analytical purity grade.

\subsection{Grapes}

Grapes from the autochthonous Montenegrin variety Vranac were used for wine production in two successive years, i.e. 2008 and 2009. Grapes were harvested in the vineyards of the "13 jul Plantaže" company at Cemovsko field, Montene- 
gro. This site belongs to the sub-region of Podgorica, which is part of the Montenegrin Basin of Lake Skadar. The geographical location is between $41^{\circ} 50^{\prime}$ and $42^{\circ} 45^{\prime}$ north latitude and $16^{\circ}$ and $17^{\circ}$ east longitude. Vranac grapes were harvested at technical maturity, with an average sugar content of $23.73^{\circ}$ Brix in both studied years (2008 and 2009). The vines were planted in 1981, and the number of vines per hectare was $4,807(2.6 \times 0.8 \mathrm{~m})$.

\subsection{Winemaking}

Winemaking was performed at the experimental winery for microvinification at the "13 jul Plantaže" company, Montenegro, in the period between September 2-21, 2008 and 2009. In total, $1 \mathrm{t}$ of grapes was harvested. Then, grapes were divided into three groups: $200 \mathrm{~kg}$ were processed for PVC vessels, $500 \mathrm{~kg}$ for Sifa tanks and $500 \mathrm{~kg}$ for Ganimede tanks. After grape crushing, the stems were removed and the pomace was placed into three fermentation tanks: a PVC vessel (capacity 100 liters), a Sifa tank (capacity 300 liters) and a Ganimede tank (capacity 300 liters) in order to study the influence of traditional (PVC vessel) and modern (Sifa and Ganimede tanks) maceration methods. In all three tanks (C - control wine, $\mathrm{S}-$ Sifa method and $\mathrm{G}$ - Ganimede method), the pomace was treated with potassium metabisulfite ( $5 \mathrm{~g} / 100 \mathrm{l}$ ) in order to suppress polyphenol oxidase enzymes and wild yeast activity, followed by inoculation with selected yeast (BDX yeast, Saccharomyces cerevisiae), provided by Lallemand (France). The yeast was prepared by rehydration $(20 \mathrm{~g} / 100 \mathrm{l})$ in water $\left(30{ }^{\circ} \mathrm{C}\right)$ and applied to the must for fermentation. The main difference between maceration in PVC vessels and modern tanks is that traditional PVC vessels are not hermetically sealed, compared to Sifa and Ganimede which have a closed design such that lees are protected against uncontrolled oxidation during fermentation. The main difference between the Sifa and Ganimede tanks is their construction and the method of pomace pumping, i.e. the distribution of the liquid which bedews the solid portion. Thus, in the Ganimede tank, carbon dioxide produced by the fermentation process allows for re-stirring cycles/délestage without the use of pumps. Under pressure, large bubbles are created through the diaphragm neck, resulting in a constant restirring of the grape marcs that will always be saturated with the liquid and well-shelled. In the Sifa tank, the pump-over system is designed for liquid recirculation (sieve over the racking port, pump-over tube, rotational sprayer). The rotational sprayer is installed on the inside of the lid and enhances the spraying intensity ensuring uniform soaking of the entire cap.

In order to study the influence of oenological additions on polyphenol extraction, wine from all three tanks (C, S and G) was separated into additional four lots in which enzymes, oak chips and grape tannins were added as follows: (1) wine without additions (TM - traditional maceration or control), (2) wine with the addition of enzymes (ENZ - enzymatic maceration), (3) wine with the addition of enzymes and oak chips (ENZ-OC enzymatic maceration in presence of oak chips) and (4) wine with the addition of enzyme, oak chips and grape tannins (ENZ-OC-GT - enzymatic maceration in the presence of oak chips and grape tannins). Enzymes (Lallzyme EX-V, provided by Lallemand, France) were added at $2 \mathrm{~g} / \mathrm{hl}$, the dose of oak chips was $100 \mathrm{~g} / \mathrm{hl}$ (French oak chips, Pronektar) and the dose of tannins was $20 \mathrm{~g} / \mathrm{hl}$, produced from non-fermented grape seeds provided by AEB (Italy). Lallzyme EX-VTM was used since it increases the extraction of the intracellular polyphenolic content from red grapes, allows for complete and rapid release of anthocyanins and leads to a more efficient release of tannins, leading to stable anthocyanin-tannin compounds. Wines were produced in two consecutive years (2008 and 2009) by applying the same winemaking procedures. In total, 12 lots were obtained for each year, or 24 lots over both years of production (2008 and 2009). All wines were dry wines, with a reducing sugar content between 1 and $2 \mathrm{~g} / \mathrm{l}$.

Maceration and fermentation was carried out for 8 days. During the fermentation, the pomace in the all tanks was "pumped over" four times a day, for 48 hours, then six times a day to the end of fermentation. Pomace in PVC tanks was mechanically "pumped over", while in the Sifa and Ganimede tanks, automatic mode was used. The temperature of fermentation ranged from 23 to 30 ${ }^{\circ} \mathrm{C}$.

The wines were stabilized at $-4{ }^{\circ} \mathrm{C}$ for a period of two months for tartrate stabilization and bottled. Bottled wines were stored at $10-15{ }^{\circ} \mathrm{C}$ in a cellar and analyzed ten months after production.

\subsection{Determination of total polyphenols}

All spectrophotometric measurements were carried out with an Agilent $8453 \mathrm{UV}$-Vis spectrophotometer, using a $1 \mathrm{~cm}$ cuvette optical path.

The Folin-Ciocalteu method [26, 27] was used for the determination of total phenolics. In brief, an aliquot $(1 \mathrm{ml})$ of appropriately diluted 
wine was added to a $10 \mathrm{ml}$ volumetric flask, containing $5 \mathrm{ml}$ of distilled water. A volume of $0.5 \mathrm{ml}$ of Folin-Ciocalteu phenolic reagent was added and mixed. After $3 \mathrm{~min}, 1.5 \mathrm{ml}$ of an $\mathrm{Na}_{2} \mathrm{CO}_{3}$ solution $(2 \mathrm{~g} / \mathrm{l})$ was added, followed by the addition of distilled water, making up the total volume to $10 \mathrm{ml}$. After 16 min of incubation at $50{ }^{\circ} \mathrm{C}$ (water bath) in sealed flasks, samples were cooled and the absorbance was read at $765 \mathrm{~nm}$ against a blank prepared with distilled water. A calibration curve was constructed using a gallic acid standard solution (0$100 \mathrm{mg} / \mathrm{l}$ ) using the same procedure as above. The concentration of total phenolics was expressed as gallic acid equivalents (mg/l GAE).

\subsection{Determination of total anthocyanins}

Determination of total anthocyanins was performed by the method proposed by Di Stefano et al. (1989) [28]. Samples were diluted with a solution consisting of $\mathrm{C}_{2} \mathrm{H}_{5} \mathrm{OH} / \mathrm{H}_{2} \mathrm{O} / \mathrm{HCl}=69 / 30 / 1$ $(v / v / v)$ and the absorbance was measured at 540 $\mathrm{nm}$. Because of the lack of a standard, the total anthocyanin content was calculated using the following equation proposed by Di Stefano et al. (1989)

$$
\begin{gathered}
\mathrm{TA}_{540} \mathrm{~nm}(\mathrm{mg} / \mathrm{l})=\mathrm{A}_{540} \mathrm{~nm} \cdot 16.7 \cdot \mathrm{d} \\
\left(A_{540 \mathrm{~nm}}-\text { absorbance at } 540 \mathrm{~nm}, \mathrm{~d}-\text { dilution }\right)
\end{gathered}
$$

expressed as malvidin-3-glucoside equivalents.

\subsection{Determination of total flavan-3-ols}

The concentration of total flavan-3-ols was measured using the $p$-(dimethylamino)cinnamaldehyde ( $p$-DMACA) method $[27,28]$ and the content was expressed as catechin equivalents (CE $\mathrm{mg} / \mathrm{l})$ of the wines. An aliquot $(1 \mathrm{ml})$ of wine appropriately diluted with water was added to a $10 \mathrm{ml}$ volumetric flask, followed by three drops of glycerol and $5 \mathrm{ml}$ of $p$-DMACA. The total volume was made up to $10 \mathrm{ml}$ with methanol, and after $7 \mathrm{~min}$ the absorbance was read at $640 \mathrm{~nm}$ against the blank (methanol). The DMACA reagent was prepared before use, containing $1 \%(w / v) p$-DMACA in a cold mixture of methanol and $\mathrm{HCl}(4: 1)$.

\subsection{Determination of color intensity and hue}

The color intensity is defined as the sum of the absorbances at $420 \mathrm{~nm}, 520 \mathrm{~nm}$ and $620 \mathrm{~nm}$ [29]. The hue of the wine (a measure of the redness of the wine) was defined as the $\mathrm{A}_{420} / \mathrm{A}_{520}$ ratio [14]. A direct measurement of wine absorbance at 420 , 520 and $620 \mathrm{~nm}$ was carried out using a cuvette with a $2 \mathrm{~mm}$ optical path and the color intensity (CI) and hue $(\mathrm{H})$ were calculated [27, 29].

\subsection{Sensorial analysis}

Sensory analysis was carried out by a committee of 20 expert judges (ten women and ten men). All evaluations were conducted in a standard sensory-analysis chamber [30], equipped with separate booths. There was a uniform source of lighting, absence of noise and distracting stimuli, and the ambient temperature maintained between 19 and $22{ }^{\circ} \mathrm{C}$. Wines $(30 \mathrm{ml})$ were presented in standard wine glasses [31], covered with a Petri dish to minimize the escape of volatile components and randomly coded with three-digit numbers. Judges were asked to rate all descriptors using a 100-point rating method: maximum 15 points for clarity, maximum 30 points for bouquet, maximum 44 points for flavor and maximum 11 points for harmony [32]. The intensity level of each descriptor was then expressed as the mean value of all the judges from two different tasting sessions.

\subsection{Statistical analysis}

The statistical evaluation, including means, standard deviations and principal component analysis (PCA), was performed using the PC software package TANAGRA 1.4.28 (Lyon, France). The Student-Newman-Keuls multiple comparisons test on the mean values was applied to the results of the concentrations of the different phenolics to ascertain possible significant differences between the studied wines.

\section{RESULTS AND DISCUSSION}

Spectrophotometric methods are affordable techniques with low reagent consumption and rapid measurement and are widely used for wine and grape analyses to follow the changes of polyphenolic contents during grape ripening and during the winemaking process. In this study, we used standardized spectrophotometric measurements on Vranac wines in order to study the content of total phenols (TP), total flavonoids (TF) and total flavan-3-ols $\left(\mathrm{TF}_{3-\mathrm{ols}}\right)$, as well as color intensity (CI) and hue $(\mathrm{H})[3,16]$. The results are presented in Table 1. Wines were produced in 2008 and 2009 by applying same vinification procedures, including the addition of enzymes (ENZ), enzymes and oak chips (ENZ-OC) and enzymes, oak chips and grape tannins (ENZ-OC-GT). Maceration was performed in a traditional way as well as using modern Sifa and Ganimede tanks.

As can be seen in Table 1, the total phenol content ranged from 1,950 to $3,280 \mathrm{mg} / \mathrm{l} \mathrm{GAE}$ 
(mean 2,724 mg/l GAE). All wines presented a relatively high concentration of total anthocyanins, ranging between 600 and $870 \mathrm{mg} / \mathrm{l}$ (mean 718 $\mathrm{mg} / \mathrm{l}$ ), and the content of total flavan-3-ols ranged between 247 and $396 \mathrm{mg} / \mathrm{l}$ (mean value $330 \mathrm{mg} / \mathrm{l}$ ).
These results are comparable to those reported for Macedonian Vranec wines produced under different vinification conditions [16]. Color intensity and hue ranged between 4.25 and 6.29 and 0.25 to 0.31 , respectively.

\section{Table 1}

Content of total phenols, anthocyanins, flavan-3-ols, color intensity and hue of Vranac wines produced in the traditional way and in Sifa and Ganimede tanks, in the presence of enzyme, oak chips and grape tannins

\begin{tabular}{|c|c|c|c|c|c|c|}
\hline $\begin{array}{l}\text { Vinification } \\
\text { alternative }\end{array}$ & Wines & $\begin{array}{c}\mathrm{TP} \\
(\mathrm{mg} / \mathrm{l})\end{array}$ & $\begin{array}{c}\text { TA } \\
(\mathrm{mg} / \mathrm{l})\end{array}$ & $\begin{array}{l}\mathbf{T F}_{\text {3-ols }} \\
(\mathrm{mg} / \mathrm{l})\end{array}$ & CI & $\mathrm{H}$ \\
\hline & & & 2008 & & & \\
\hline \multicolumn{7}{|l|}{ Control } \\
\hline $\mathrm{TM}$ & C1-08 & 1950 & $600 \mathrm{a}$ & $256 \mathrm{a}$ & $4.25 \mathrm{a}$ & $0.25 \mathrm{a}$ \\
\hline ENZ & C2-08 & $2180 a$ & $612 \mathrm{a}$ & $267 \mathrm{a}$ & $4.35 \mathrm{a}$ & $0.26 \mathrm{a}$ \\
\hline ENZ-OC & C3-08 & $2190 \mathrm{a}$ & $606 a$ & $247 \mathrm{a}$ & $4.38 \mathrm{a}$ & $0.25 \mathrm{a}$ \\
\hline ENZ-OC-GT & C4-08 & $2250 a$ & $610 \mathrm{a}$ & $248 \mathrm{a}$ & $4.47 \mathrm{a}$ & $0.26 \mathrm{a}$ \\
\hline \multicolumn{7}{|l|}{ Sifa } \\
\hline $\mathrm{TM}$ & S1-08 & $2210 a$ & $659 \mathrm{~b}$ & $300 \mathrm{~b}$ & $4.28 \mathrm{a}$ & $0.26 \mathrm{a}$ \\
\hline ENZ & S2-08 & $2670 \mathrm{~b}$ & $767 \mathrm{c}$ & $317 b$ & $5.18 b$ & $0.27 \mathrm{a}$ \\
\hline ENZ-OC & S3-08 & $2420 a$ & $746 \mathrm{c}$ & $310 \mathrm{~b}$ & $4.81 \mathrm{c}$ & $0.28 \mathrm{a}$ \\
\hline ENZ-OC-GT & S4-08 & $2410 a$ & $775 \mathrm{c}$ & $313 b$ & $5.21 \mathrm{~b}$ & $0.28 \mathrm{a}$ \\
\hline \multicolumn{7}{|l|}{ Ganimede } \\
\hline $\mathrm{TM}$ & G1-08 & $3010 \mathrm{c}$ & $850 \mathrm{~d}$ & $362 c$ & $6.01 \mathrm{~d}$ & $0.31 \mathrm{~b}$ \\
\hline ENZ & G2-08 & $3105 d$ & $840 \mathrm{~d}$ & $368 \mathrm{c}$ & $5.95 \mathrm{~d}$ & $0.31 b$ \\
\hline ENZ-OC & G3-08 & $3180 \mathrm{~d}$ & $860 \mathrm{~d}$ & $374 \mathrm{c}$ & $6.29 \mathrm{~d}$ & $0.31 b$ \\
\hline \multirow[t]{2}{*}{ ENZ-OC-GT } & G4-08 & $3270 d$ & $870 \mathrm{~d}$ & $355 \mathrm{c}$ & $6.01 \mathrm{~d}$ & $0.31 \mathrm{~b}$ \\
\hline & & & 2009 & & & \\
\hline \multicolumn{7}{|l|}{ Control } \\
\hline $\mathrm{TM}$ & C1-09 & $2450 \mathrm{a}$ & $640 \mathrm{~b}$ & $300 \mathrm{~b}$ & $4.49 \mathrm{a}$ & $0.27 \mathrm{a}$ \\
\hline ENZ & C2-09 & $2700 \mathrm{~b}$ & $645 b$ & 338 & $4.43 a$ & $0.27 \mathrm{a}$ \\
\hline ENZ-OC & C3-09 & $2810 \mathrm{c}$ & $640 \mathrm{~b}$ & $314 b$ & $4.41 \mathrm{a}$ & $0.27 \mathrm{a}$ \\
\hline ENZ-OC-GT & C4-09 & $2830 \mathrm{c}$ & $650 \mathrm{~b}$ & 338 & $4.52 \mathrm{a}$ & $0.26 \mathrm{a}$ \\
\hline \multicolumn{7}{|l|}{ Sifa } \\
\hline $\mathrm{TM}$ & S1-09 & $2590 \mathrm{~b}$ & $674 b$ & $314 b$ & $4.86 \mathrm{c}$ & $0.27 \mathrm{a}$ \\
\hline ENZ & S2-09 & $2990 \mathrm{c}$ & $706 c$ & 381 & $4.62 \mathrm{c}$ & $0.28 \mathrm{a}$ \\
\hline ENZ-OC & S3-09 & $3280 \mathrm{~d}$ & $744 c$ & 396 & $5.09 \mathrm{~b}$ & $0.29 \mathrm{a}$ \\
\hline ENZ-OC-GT & S4-09 & $2850 \mathrm{c}$ & $765 \mathrm{c}$ & $354 \mathrm{c}$ & $5.15 b$ & $0.28 \mathrm{a}$ \\
\hline \multicolumn{7}{|l|}{ Ganimede } \\
\hline $\mathrm{TM}$ & G1-09 & $2590 \mathrm{~b}$ & $674 b$ & $314 b$ & $4.86 \mathrm{c}$ & $0.27 \mathrm{a}$ \\
\hline ENZ & G2-09 & $3095 d$ & $750 \mathrm{c}$ & 390 & $5.10 \mathrm{~b}$ & $0.29 \mathrm{a}$ \\
\hline ENZ-OC & G3-09 & $3100 d$ & $750 \mathrm{c}$ & $366 \mathrm{c}$ & $5.19 \mathrm{~b}$ & $0.30 \mathrm{~b}$ \\
\hline ENZ-OC-GT & G4-09 & $3250 \mathrm{~d}$ & 790 & 390 & $5.16 \mathrm{~b}$ & $0.30 \mathrm{~b}$ \\
\hline
\end{tabular}

Abbreviations: TM-traditional maceration, ENZ-enzymatic maceration, ENZ-OC-enzymatic maceration in presence of oak chips, ENZ-OC-GT- enzymatic maceration in presence of oak chips and grape tannins

$\mathrm{C}-$ Control wines

$\mathrm{S}$ - Sifa method (Sifa fermentation tank)

$\mathrm{G}$ - Ganimede method (Ganimede fermentation tank)

$08-2008$ vintage, $09-2009$ vintage

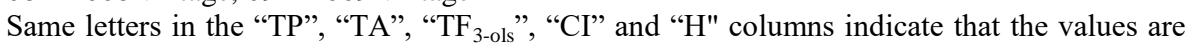
not significantly different $(p>0.05)$, analyzed by the Student-Newman-Keuls test of multiple comparisons 


\subsection{Influence of vintage}

In general, regardless the vinification protocol used, wines produced in the 2009 vintage presented slightly higher average amounts of total phenols and flavan-3-ols $(2878 \mathrm{mg} / \mathrm{l}$ and $350 \mathrm{mg} / \mathrm{l}$, respectively), compared to the wines from the 2008 vintage $(2570 \mathrm{mg} / \mathrm{l}$ and $310 \mathrm{mg} / \mathrm{l}$, respectively). On the contrary, the average contents of anthocyanins were slightly higher in the wines produced in 2009 , as was color intensity. The average values of total anthocyanins were 733 and 702 $\mathrm{mg} / \mathrm{l}$ and the color intensity values were 5.1 and 4.82, for 2008 and 2009, respectively. These differences can be explained by variations in weather conditions between the growing seasons, such as differences in temperature and rainfall. The highest correlations were noted between the total polyphenolic content and temperature, and between the total polyphenolic content and rainfall. The average temperature in 2009 , during the three months before the grape harvest, was higher $(26.4$ $\left.{ }^{\circ} \mathrm{C}\right)$ compared to the same period in $2008\left(25.8^{\circ} \mathrm{C}\right)$. Moreover, there was less rainfall in $2009\left(31 \mathrm{l} / \mathrm{m}^{2}\right)$ compared to $2008\left(39.8 \mathrm{l} / \mathrm{m}^{2}\right)$. Thus, the weather and climate conditions could be the reason for the differences in phenolic levels in the wines produced in the two vintage years. Previous studies have attributed differences in the level of phenolic compounds in grapes of the same genotype grown in different years to changes in temperature, water availability (drought or precipitation), light intensity, salinity and pollination [33, 34]. Our findings are in agreement with the results from previous research studies, indicating that weather conditions influence the content of stilbenes in wine [35, 36]. However, the mechanism behind the effects of temperature and rainfall on the phenolic content in plants is not clearly understood.

\subsection{Influence of the maceration method}

Concerning the influence of maceration used for wine production, it was found that modern vinification methods significantly influenced the content of total phenols, total anthocyanins, total flavan-3-ols, color intensity and hue in wine. Actually, enhanced extraction of polyphenols occurred in the Sifa and Ganimede tanks as a result of more intensive maceration compared to the traditional PVC vessel, where mechanical mixing of the pomace is performed. Sifa and Ganimede tanks are closed systems, in which the lees are protected against uncontrolled oxidation during fermentation and more efficient mixing of the lees is performed.
Therefore, higher contents of TP, TA, $\mathrm{TF}_{3-\mathrm{ols}}, \mathrm{CI}$ and $\mathrm{H}$ were observed in the wines produced in the Sifa (S) and Ganimede (G) tanks compared to traditional and control wines (C). Thus, the average values for TP in C, S, G wines and were: 2,143, 2,428 and $3,141 \mathrm{mg} / \mathrm{l}$, respectively, in 2008 , and 2,698, 2,928 and 3,009 mg/l, respectively, in 2009. Average amounts of anthocyanins and color intensity were: 607,737 and $855 \mathrm{mg} / \mathrm{l}$ and 4, 4.87 and 6.07 in 2008 for C, S, G wines, respectively, and 644, 722 and $741 \mathrm{mg} / \mathrm{l}$ and 4.46, 4.93 and 5.08 in 2009 for C, S, G wines, respectively. Flavan-3-ols presented the same trend between wines, with the lowest value observed in control wines and the highest value seen in Ganimede wines, for both years of production. In fact, it is known that winemaking technology and maceration significantly influence the extraction of phenolic compounds from grapes into the wine [16]. Moreover, watertight tanks such as Ganimede and Sifa, which are hermetically sealed, prevent wine oxidation and allow for the efficient and selective extraction of polyphenols, and thus the extraction of anthocyanins and flavan-3-ols. In these tanks, especially in Ganimede, strong mechanical action is not needed, which prevents aggressive action on the cap. All the energy needed originates from the natural $\mathrm{CO}_{2}$ produced during the fermentation process. It flows in the tanks and allows for re-stirring cycles/délestage without the use of pumps, leading to improved extraction of polyphenols from the grapes, as was observed in our study. These results are in accordance with previous studies [37, 38].

\subsection{Influence of oenological additions}

The influence of oenological additions was assessed, with a higher phenolic extraction rate seen in wines containing oenological products compared to the control wines. The lowest concentrations of total phenols, anthocyanins and flavan3 -ols, as well as the lowest values for color intensity and hue, were measured in the control wines which did not contain any oenological products, regardless of the maceration method used in winemaking. Concerning the total phenols, ENZOC wines presented the highest amounts, even though statistically significant differences between ENZ (2,790 $\mathrm{mg} / \mathrm{l}$, on average), ENZ-OC $(2,830$ $\mathrm{mg} / \mathrm{l}$, on average) and ENZ-OC-GT $(2,810 \mathrm{mg} / \mathrm{l}$, on average) wines were not observed $(p>0.05)$. The same situation was noted for the content of anthocyanins, in which the highest concentration was measured for the ENZ-OC-GT wines, but there was no statistical difference $(p>0.05)$ be- 
tween the ENZ (720 mg/l, on average), ENZ-OC (724 mg/l, on average) and ENZ-OC-GT (743 $\mathrm{mg} / \mathrm{l}$, on average) wines. ENZ-OC-GT wines presented the highest color intensity $(5.09$, on average) and the content of flavan-3-ols was the highest in ENZ wines (343 mg/l, on average). Also, the addition of oak chips influenced directly on increasing of their levels. Anthocyanins are the first compounds that are extracted from grape skins during the first days of maceration, followed by the extraction of seed flavan-3-ols when an appropriate amount of alcohol has been formed. It is likely that the highest content of anthocyanins in ENZ-OCGT wines was a consequence of the oxidative protection of must and wine by the addition of oak chips and tannins, allowing for the increased extraction of skin compounds, and among them the anthocyanins. Further mechanisms responsible for color enhancement (e.g. anthocyanins) in OC-GT samples may be the stabilization of native (e.g. monomeric) anthocyanins by tannins from the added oak and grape tannins via adduct or polymer formation. Another reason could be the use of the commercial grape product (grape tannins) which could contain material from an origin other than grape seeds (such as grape skins). When added during fermentation, this could also increase anthocyanin levels [39].

\subsection{Sensory evaluation of wines}

Average values of the olfactory descriptors (clarity, bouquet, flavor and harmony) obtained from the sensory analysis of Vranac wines produced with appropriate maceration protocols (TM - traditional maceration, ENZ - enzymatic maceration, ENZ-OC - enzymatic maceration in the presence of oak chips, ENZ-OC-GT - enzymatic maceration in the presence of oak chips and grape tannins), during two years (2008 and 2009), are presented as spider web diagrams (Fig. 1). As expected, control wines produced by traditional maceration (TM) and enzymatic wines (ENZ) were characterized with less clarity (on average: 12.15 and 12.27 , respectively) and bouquet (on average: 24.92 and 25.14, respectively), as well as less flavor (mean value: 37.03 and 37.48, respectively) and harmony (mean value: 8.37 and 8.50 , respectively) than ENZ-OC (mean values for clarity, bouquet, flavor and harmony: 12.52, 25.51, 37.68 and 8.74, respectively) and ENZ-OC-GT wines (mean values for clarity, bouquet, flavor and harmony: 13.34, 26.9, 38.34 and 9.32, respectively). Differences between TM and ENZ wines were not statistically significant when analysis of variance was applied to the sensory scores $(p>0.05)$. Usage of oak chips (OC) and grape tannins (GT) positively affected the sensorial quality of wines and improved the intensity and complexity of wine flavor. ENZ-OC-GT wines presented most complex bouquet and best harmony compared to all other wines, obtaining the highest sensory scores, because of the presence of oak chips and grape tannins which influenced the complexity of the wines.

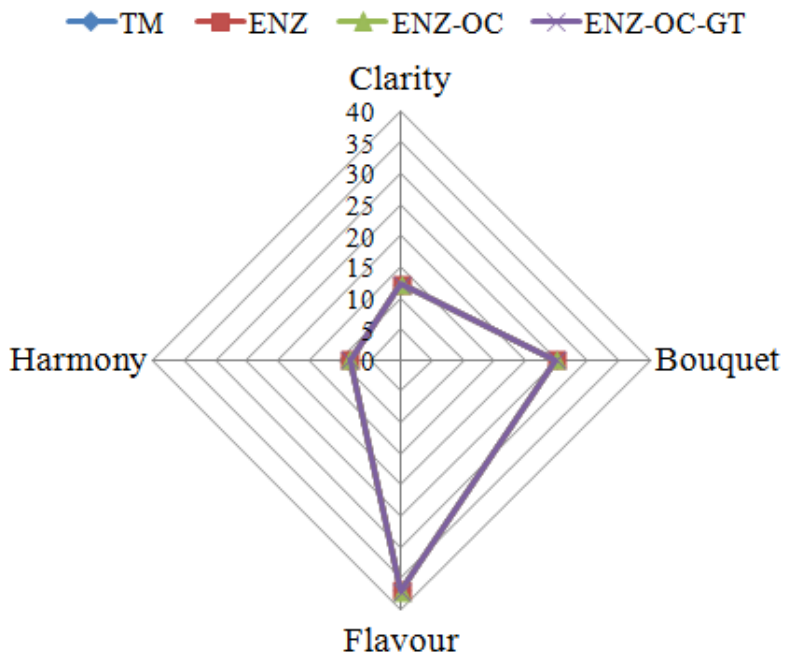

Fig. 1. Sensory evaluation of Vranac wines produced with different maceration protocols: TM - traditional maceration, ENZ - enzymatic maceration, ENZ-OC - enzymatic maceration in the presence of oak chips and ENZ-OC-GT - enzymatic maceration in the presence of oak chips and grape tannins.

\subsection{Principal component analysis}

Principal component analysis (PCA) was applied to the parameters obtained by the spectrophotometric analyses of Vranec wine samples produced using different vinification protocols. PCA was performed to determine which parameter, i.e. vintage (2008 and 2009), maceration (traditional, Sifa and Ganimede) and oenological products (enzyme, oak chips and grape tannin), can be used to distinguish wines. For this purpose, the results for total phenolics (TP), anthocyanins (TA), flavan-3ols (TF-3-ols), color intensity (CI) and hue (H) were used.

In Figure 2a it can be seen that the first principal component (PC1) accounts for $85.53 \%$ of the variability and the second principal component (PC2) accounts for $11.21 \%$ from the variability, i.e. together, PC1 and PC2 account for $96.73 \%$ of the total variance. Grouping of the samples was mainly observed according to the vintage, with a clear separation of the wines produced in 2008 and 
2009. Thus, wines produced in 2008 were located in the negative part of $\mathrm{PC} 2$, while wines from the 2009 vintage were in the upper, positive part of PC2. Within the main groupings, smaller subgroups were noted. Thus, in the first group, wines from the 2008 vintage were sub-divided according to maceration, with three groups: (i) wines macerated and fermented in the traditional way ${ }^{\mathrm{TM}}$, (ii) wines macerated and fermented in Sifa tanks (S) and (iii) wines macerated and fermented in Ganimede tanks (G). In the second group, samples from the 2009 vintage were subdivided into two subgroups: wines macerated and fermented with traditional maceration (TM) were clearly separated from the wines macerated and fermented in Sifa and Ganimede tanks.

\section{PC1 vs. PC2: $96.73 \%$}

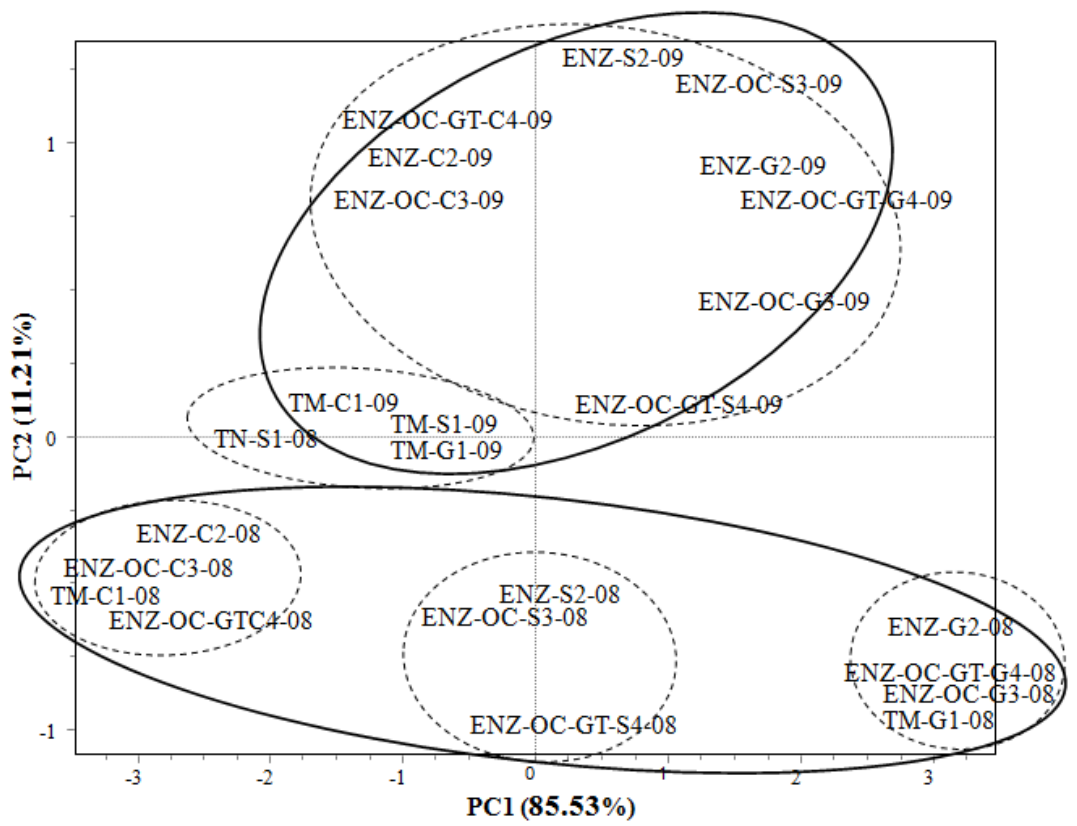

Fig. 2 a. Classification of Vranac wines analyzed as a function of PC1 and PC2 for all analyzed variables

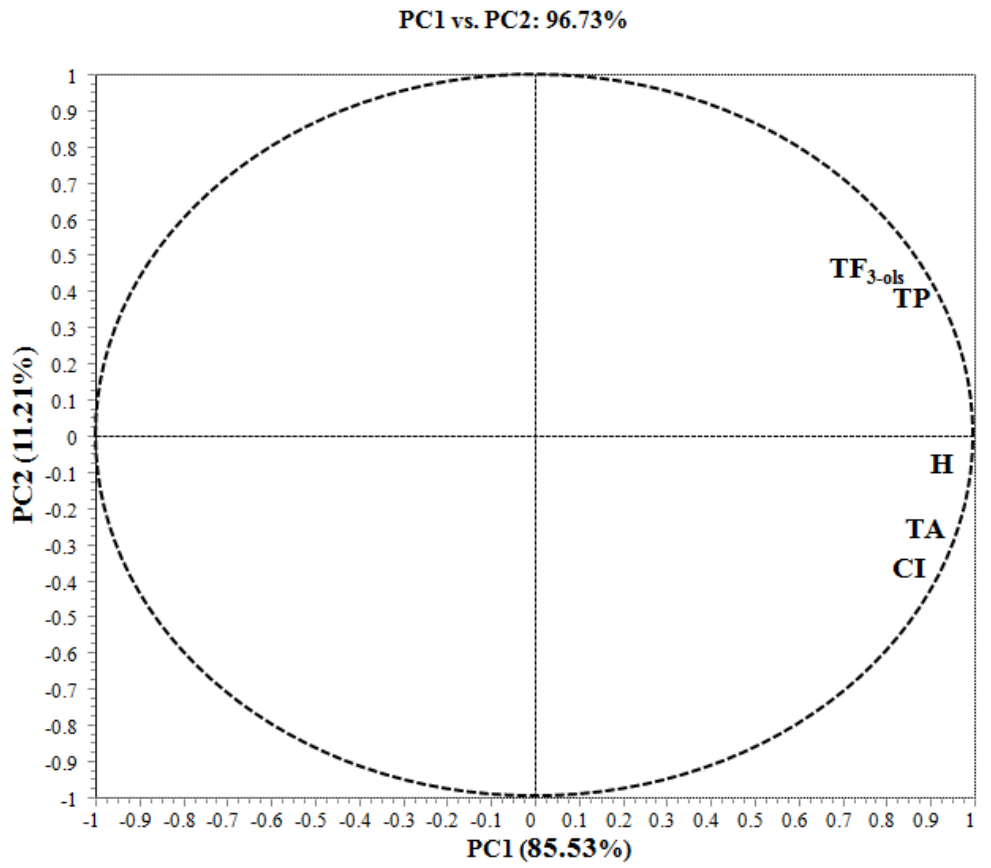

Figure 2 b. PCA loadings of variables based on spectrophotometric data for total phenolics (TP), total anthocyanins $(\mathrm{TA})$, total flavan-3-ols $\left(\mathrm{TF}_{3-\mathrm{ols}}\right)$, color intensity $(\mathrm{CI})$ and hue $(\mathrm{H})$. 
As can be seen from the correlation scatterplot in Figure 2b, all parameters contributed positively to PC1. With regard to PC2, total phenols (TP) and total flavan-3-ols ( $\left.\mathrm{TF}_{3 \text {-ols }}\right)$ contributed positively to $\mathrm{PC} 2$, while anthocyanins (TA), color intensity $(\mathrm{CI})$ and hue $(\mathrm{H})$ contributed negatively to PC2. This means that wines from the 2009 vintage were richer in phenols and flavanols compared to wines produced in 2008, which presented higher concentrations of anthocyanins and were richer in color and hue.

\section{CONCLUSIONS}

Vranac grapes are the most important red variety in Montenegro. In this study, a quantitative analysis of total phenols, anthocyanins and flavan3-ols, as well as color intensity and hue, was performed on Vranac wines, showing that the wines were very rich in phenolics and color. In general, wines from the 2009 vintage presented higher contents of phenols and flavan-3-ols and lower anthocyanin levels, probably due to the climatic conditions. Moreover, the results show that maceration methods influence the phenolic profile of wine, with the highest $\mathrm{TP}, \mathrm{TA}, \mathrm{TF}_{3-\text { ols }}, \mathrm{CI}$ and $\mathrm{H}$ values found in wines macerated in Ganimede tanks. Oenological additions (enzyme, oak chips and grape tannins) increased the phenolic levels compared to the control wine, enhancing their extraction in the wines. PCA provided a grouping of the wines according to the vintage and maceration and fermentation methods. Wines presented a complex bouquet and harmony when fermented in the presence of oak chips and grape tannins, which had a positive influence on the complexity of the wines.

\section{REFERENCES}

[1] R. R. Villamor, C. F. Ross, Wine matrix compounds affect perception of wine aromas, Annu. Rev. Food. Sci. Technol. 4, 1-20 (2013).

[2] V. Ivanova-Petropulos, S. Durakova, A. Ricci, G. P. Parpinnelo, A. Versari, Extraction of natural occurring bioactive compounds and change in antioxidant capacity of Macedonian red wines during vinification, J. Food Sci. Techol. 53 (6), 2634-2643 (2016).

[3] V. Ivanova, M. Stefova, B. Vojnoski, Assay of the phenolic profile of Merlot wines from Macedonia: effect of maceration time, storage, $\mathrm{SO}_{2}$ and temperature of storage, Maced. J. Chem. Chem. Eng. 28, 141-149 (2009).

[4] L. W. Wulf, C. W. Nagel, High-pressure liquid chromatography separation of anthocyanins of Vitis vinifera, Am. J. Enol. Vitic., 29 (1), 42-49 (1978).

[5] F. Mattivi, R. Guzzon, U. Vrhovsek, M. Stefanini, R. Velasco, Metabolite profiling of grape: flavonols and anthocyanins, J. Agric. Food Chem. 54, 7692-7702 (2006).

[6] L. J. Porter, L. N. Hirtstich, B. G. Chang, The conversion of procyanidins and prodelphinidins to cyanidins and delphinidins, Phytochem. 25 (1), 223-230 (1986).

[7] P. Ribereau-Gayon, La couleur des vins. Aliment Vie, $\mathbf{5 3}$ (10), 232-248.

[8] T. C. Somers, The polymeric nature of wine pigments, Phytochem. 10, 2175-86 (1971).

[9] J. L. Robichaud, A. C. Noble, Astringency and bitterness of selected phenolics in wine, J. Sci. Food Agric. 53, 343-353(1990).

[10] V. Kovac, E. Alonso, M. Bourzeix, E. Revilla, Effect of several enological practices on the content of catechins and proanthocyanidins of red wines, J. Agric. Food Chem. 40 (10), 1953-1957(1992).

[11] R. Gil-Muñoz, E. Gómez-Plaza, A. Martínez, J. M. López-Roca, Evolution of the CIELAB and other spectrophotometric parameters during wine fermentation. Influence of some pre and postfermentative factors, Food Res. Int. 30 (9), 699-705 (1997).

[12] G. Mazza, L. Fukumoto, P. Delaquis, B. Girard, B. Ewert, Anthocyanins, phenolics, and color of Cabernet franc, Merlot, and Pinot noir wines from British Colombia, J. Agric. Food Chem. 47 (10), 4009-4017 (1999).

[13] U. Fischer, M. Strasser, K. Gutzler, Impact of fermentation technology on the phenolic and volatile composition of German red wines, Eur. Food Res. Tech. 35 (1), 8194 (2000).

[14] K. L. Sacchi, L. F. Bisson, D. O. Adams, A review of the effect of winemaking techniques on phenolic extraction in red wines, Am. J. Enol. Vitic., 56 (3),197-206 (2005).

[15] V. Ivanova, Á. Dörnyei, L. Márk, B. Vojnoski, T. Stafilov, M. Stefova, F. Kilár, Polyphenolic content of Vranec wines produced by different vinification conditions, Food Chem. 124 (1), 316-325 (2011).

[16] V. Ivanova, B. Vojnoski, M. Stefova, Effect of winemaking treatment and wine aging on phenolic content in Vranec wines, J. Food Sci. Technol. 49 (2), 161-172 (2012).

[17] I. Revilla, M. L. González-San José, Compositional changes during the storage of red wines treated with pectolytic enzymes: low molecular-weight phenols and flavan-3-ol derivative levels, Food Chem. 80, 205-214 (2003).

[18] A. B. Bautista-Ortín, A. Martínez-Cutillas, J. M. RosGarcía, J. M. López-Roca, E. Gómez-Plaza, Improving colour extraction and stability in red wines: The use of maceration enzymes and enological tannins, Int. J. Food Sci. Techol. 40, 867-878(2005).

[19] T. Garde Cerdán, D. Torrea Goñi, C. Ancín Azpilicueta, Accumulation of volatile compounds during ageing of two red wines with different composition, J. Food Eng. 65 (3), 349-356(2004).

[20] S. Rayne, S. Sheppard, T. Di Bello, N. J. Eggers, Chromatic characteristics and optically derived compositional descriptors of micro-oxygenated wines from Vitis vinifera cv. merlot and cabernet sauvignon, Food Bioprocess. Technol. 4, 254-265 (2011). 
[21] M. Cano-López, B. Bautista-Ortín, F. Pardo-Minguez, J. M. López-Roca, E. Gómez-Plaza, Sensory descriptive analysis of a red wine aged with oak chips in stainless steel tanks or used barrels: Effect of the contact time and size of the oak chips, J. Food Quality, 31 (5), 645-660 (2008).

[22] Z. Božinović, Ampelography, Akademik. Skopje, Macedonia, 2005.

[23] V. Maras, D. Raičević, M. Tomić, V. Kodžulovic, B. Knežević, M. Cizmović, Yield and quality of grapes and wine of the varieties Vranac, Primitivo and Negro amaro, Acta Hortic. 931, 371-375 (2012).

[24] R. Pajović, D. Raičević, T. Popović, P. Sivilotti, K. Lisjak, A. Vanzo, Polyphenolic characterisation of Vranac, Kratosija and Cabernet Sauvignon (Vitis vinifera L. cv.) grapes and wines from different vineyard locations in Montenegro, S. Afr. J. Enol. Vitic. 35 (1), 134-143 (2014).

[25] D. Raicevic, R. Pajovic-Scepanovic, S. Mijovic, T. Popovic, Phenolic compounds of red wines in Podgorica subregion (Montenegro), Agricult. Forest. 61(4), 359368 (2015).

[26] K. Slinkard, V. L. Singleton, Total phenol analysis: automation and comparison with manual methods, Am. J. Enol. Vitic. 28, 49-55 (1977).

[27] V. Ivanova, M. Stefova, F. Chinnici, Determination of the polyphenol contents in Macedonian grapes and wines by standardized spectrophotometric methods, $J$. Serb. Chem. Soc., 75 (1), 45-49 (2010).

[28] R. Di Stefano, M. C. Cravero, N. Gentilini, Metodi per lo studio dei polifenoli dei vini, L'Enotecnico I, Maggio, 83-89 (1989).

[29] Y. Glories, La couleur des vins rouges II, Connaissance de la vigne et du vin, Vigne vin 18, 253-271 (1984).

[30] ISO 8589:1988, Sensory analysis - General guidance for the design of test rooms.
[31] ISO 3591:1997, Sensory analysis - Apparatus - Winetasting glass.

[32] Resolution OIV/concours 332A/2009. OIV standard for international wine and spirituous beverages of vitivinicultural origin competitions. Paris, France: International Organisation of Vine and Wine, 2009.

[33] S. D. Cohen, J. M. Tarara, J. A. Kennedy, Assessing the impact of temperature on grape phenolic metabolism, Anal. Chim. Acta. 621, 57-67, 2008.

[34] D. Šebela, Z. Turóczy, J. Olejníčková, M. Kumšta, R. Sotolár, Effect of ambient sunlight intensity on the temporal phenolic profiles of Vitis vinifera L. cv. Chardonnay during the ripening season - A Field study, S. Afr. J. Enol. Vitic. 38, 94-102, (2017).

[35] D. M. Goldberg, J. Yan, E. Ng, E. P. Diamandis, A. Karumanchiri, G. Soleas, A. L. Waterhouse, A global survey of trans-resveratrol concentrations in comercial wines, Am. J. Enol. Vitic. 46, 159-165 (1995).

[36] L. Bavaresco, E. Cantu, M. Fregoni, M. Trevisan, Constitutive stilbene contents of grapevine cluster stems as potential source of resveratrol in wine, Vitis, 36 (3), 115-118 (1997).

[37] T. Garde-Cerdán, I. Jarauta, S. M. Rosario, C. AncínAzpilicueta, Comparative study of the volatile composition in wines obtained from traditional vinification and from the Ganimede method, J. Sci. Food Agric. 88 (10), 1777-1785 (2008).

[38] E. S. Vázquez, S. R. Segade, I. O. Fernández, Effect of the winemaking technique on phenolic composition and chromatic characteristics in young red wines, Eur. Food Res. Tech. 231 (5), 789-802(2010).

[39] G. Favre, Á. Peña-Neira, C. Baldi, N. Hernández, S. Traverso, G. Gil, G. González-Neves, Low molecularweight phenols in Tannat wines made by alternative winemaking procedures, Food Chem. 158, 504-512 (2014). 